\title{
Articles
}

Central European Review of Economics \& Finance

Vol. 17, No. 1(2017), pp. 65-81, D0I: 10.24136/ceref.2017.004

Dariusz Filip ${ }^{1}$

\section{MARKET CONDITIONS OF MUTUAL FUNDS FUNCTIONING IN POLAND}

The purpose of the paper is to discuss the structure of financial intermediaries market with particular reference made to mutual funds, and to present the role they have played in the financial sector. Moreover, the study focusses on the presentation of the environment of the mutual funds functioning in Poland, which is possible by comparing the level of assets values in main groups of financial institutions over the long-term perspective. Furthermore, it is essential in the cognitive context to determine the influence of market trends on the popularity of given segments of funds. The analysis has shown that the development of collective investment institutions industry in Poland is incontestable. Even though the mutual funds have gained a relatively strong position on the financial intermediaries market, they clearly give priority to the banking sector institutions. The volume of market shares of main types of funds has changed over time, which could be dependent on capital market factors.

JEL Classification Codes: G20, G23.

Keywords: mutual fund industry, development of financial institutions, assets under management, market competition.

\section{Introduction}

In terms of subject matter, the scope of this study concerns mutual funds as one of the types of collective investment institutions. Mutual funds are the entities that pool money from many individual investors to invest the thus collected funds in a diversified portfolio of securities, especially combination of stocks, bonds, money-market instruments or other assets. Each unit of the

\footnotetext{
${ }^{1}$ Ph.D., Cardinal Stefan Wyszynski University in Warsaw (UKSW), Faculty of History and Social Sciences, Institute of Sociology (economics), e-mail: d.filip@uksw.edu.pl
} 
fund share represents an investor's proportionate ownership of the fund's holdings and the income those holdings may generate (SEC, 2008).

Mutual funds provide many important benefits to investors. Some of them have remained unchanged since the first fund was established. Being the most important of all, such classic advantages include professional management and diversification. The first one involves a team of experienced professionals who conduct research and select investments in line with the given fund's objective, and also provide monitoring of the investments performance. JP.Morgan (2016) described the second benefit as the spreading of an investment across a wide range of companies and industries to ensure better protection of assets during market fluctuations. Other advantages include among others also affordability, liquidity and a low cost of trading (ICl, 2016). Affordability is achieved due to the possibility of making a decision to purchase shares for a relatively low amount of money involved in the initial of investment. Liquidity, in turn, is the ability to readily redemption shares for any reason at their current net value. Last but not least, many investors perceive the low operational cost as the greatest advantage of all. Mutual funds are relatively less expensive in comparison to the investments made directly on capital markets.

Besides the classic advantages, mutual fund participants have also benefited from many cutting-edge technological achievements as the funds have tried to offer improved services to meet the changing investors' needs, e.g. with regard to variability of products. However, funds have also the features that some investors might view as disadvantages, especially the fees and charges, but the most important drawback consists in the fact that mutual funds have never been protected by any government guarantees or insured by any institutions or agencies. Moreover, the good performance of the funds in the past is not a reliable indicator of their performance in the future.

The purpose of this study is to discuss the structure of financial intermediaries market, with particular reference made to mutual funds, it also aims at answering the question whether the mutual funds in Poland have played an increasing role in the local financial system, which is possible by comparing the value of assets held by the main groups of financial institutions. Such an approach enables the ratios of development of financial intermediaries in the financial market to be determined and analyzed in this study. The analysis also comprises the assets of different mutual fund types with the view to finding out about the trends within the investors groups for different segments of investments.

The article is organized as follows: Section 1 includes a brief review of financial literature concerning the determinants of mutual funds operations. 
Section 2 focuses on the significance of financial intermediaries in the analyzed financial market followed by Section 3 showing the ratios of development across the mutual funds industry. Finally, section 4 presents main concluding remarks.

\section{Conceptual issues and a brief literature review}

Accompanied by many periods of growth on the global securities markets, dynamic development of mutual funds industry has led to an increased interest in these financial organizations as a subject matter of research. Main stream of discussions concerning the performance of mutual funds dates back to the 1960 s decade (e.g. Friend et al., 1962; Horowitz, 1965; Treynor, 1965; Sharpe, 1966). Nowadays foreign literature on the issue consists of thousands of papers evaluating collective investment institutions from many different perspectives.

The functional conditions in which the discussed entities operate are the subject matter analyzed by Khorana and Servaes (2008) in the study concerning the future of the industry around the world. The above mentioned authors have noticed that there are still some financial intermediary industries in the analyzed countries where the mutual funds market is poorly developed, e.g. those regarded as emerging markets. In other countries with mature markets, the list of funds on offer is very long, but in general they are managed by just a handful of asset investment companies. The markets, in e.g. North America and Western Europe are characterized by a relatively high level of concentration. In respect of their functioning conditions, they have experienced a better efficiency of legal framework there. However, there is still a lot of room for improvement, especially outside the U.S., in the areas such as services and the transparent presentation of offers with clear specification of fees and expenses, among others.

The study of Khorana et al. (2005) obtained results from 56 countries concerning the influence of implementation of financial innovations on the size of the industry. Their major finding is that mutual fund markets are larger in the countries with stronger rules, laws and regulations on financial institutions and better protection of fund investors' rights. The analyzed factors that affect the size of the industry include, among others, also the level of citizens' wealth and education, the age of the given industry and the level of trading costs.

Ferreira et al. (2013) analyzed the performance determinants of openend, actively managed mutual funds operating in 27 countries, including Poland. The study was conducted on the basis of the data gathered with 
regard to 16316 equity funds in the 1997-2007 period. A large number of fund characteristics were subject to examinations, including the fund size, the family size, the fund age, relevant fees and expenses as well as the management structure. As regards the characteristics of the countries that have been taken into consideration, they include economic development, financial development, investor protection and the quality of legal institutions along with the structure of the mutual fund industry. Given the context of the functioning conditions of mutual funds, the findings on the positive correlation between the performance of a given fund and the general financial development seems to be especially interesting. The above mentioned authors conclude that the funds achieved better performance in the countries with a high level of trading activity and low trading costs. They have also noticed that mutual funds located in countries with common law tradition obtain higher returns. Moreover, good investor protection and law enforcement also have a significantly positive impact on the effects of asset management.

The first studies concerning mutual funds appeared in Polish literature at the turn of the century (e.g. Miziołek, 1997; Cekaj et al., 2001; Czempas and Lokwenc, 2001). Some of the early studies focused on the issue of performance effectiveness. There were also other studies concerning market conditions and the possibilities of funds functioning (e.g. Filip, 2007). However, it needs to be noticed that the primary analyses covered only short time periods, or only a small study sample was applied. The authors of more recent papers enjoyed a privileged position because the fund market entities were growing in size at that time. The studies of Jackowicz and Filip (2009), Olbryś (2010), Sikora (2010), Perez (2012) covered definitely longer periods or they applied more advanced empirical tools as well as enriched the local financial literature by adding new approaches or adopting some unconditional measures of returns. In general, the above mentioned studies confirmed and concluded that mutual funds had achieved better or worse performance levels in relation to market possibilities under changing investment conditions.

\section{Collective investment institutions and their competitors on the financial market}

As mentioned before, the aim of the article is to present the role played by mutual funds in the financial system, which is possible, for example, by describing the impact of external factors on the operating of mutual funds, and by determining the relevance of various financial intermediaries for the economy. According to Blake's approach (2000), apart from final market par- 
ticipants and market-makers, financial intermediaries belong to the category of major actors in the financial system. Regardless of the financial market model in a given financial system, the most important intermediaries are banks, insurance companies and collective investment institutions, including mutual funds.

Table 1 presents the values of assets held by major types of financial intermediaries. Given the aim of determining the economic significance of individual types of entities, their assets are tabulated with the GDP values in current prices.

As presented in Table 1, the banking sector has held the largest amounts of capital resources among all of the analyzed types of intermediaries in the whole period under study. The supremacy of banks on financial markets is a characteristic feature of continental financial system models (see Matysek-Jędrych, 2007). In the period 1997-2007, the value of assets under the bank management increased from PLN 247.7bn to PLN 797.3bn. Despite the presence of notable symptoms of financial crisis, the assets of banks rose to reached PLN 1,600bn. in 2015. The average rate of assets growth was $13 \%$ per year. The ratio collating the bank assets with the GDP value demonstrates the strength of this group of intermediaries. In the above mentioned period before the crisis, the share of bank assets in the GDP constantly increased and amounted to max. 0.67. However, in the first year after the lower rate of the GDP growth was observed in Poland, i.e. in 2008 , the share of banks' assets in the GDP increased about $20 \%$ to the 0.80 level, which means that the growth rate of the banks' assets value was higher than that of the GDP. At the end of period under study, the analyzed ratio increased to the 0.89 value again. In the second half of the discussed period, the significance of the banking sector in the economy was enhanced thanks to the expansive policy that commercial banks pursued at the time.

Mutual funds are the second group described in terms of the possessed assets value. The analysis of level and dynamics of assets' changes will be presented in the next section, but the ratio of total assets to the value of GDP is worth mentioning here. It should be pointed out that the share of mutual fund assets in the market value of all goods and services generated by factors of production was growing practically from 2000 (see Table 1). At the end of 2007, the ratio of mutual funds total value to the GDP was 0.11. That was resulted from the upward market trends for mutual funds and their relatively large popularity. The wave of units' withdrawals from alternative forms of investments was notable when the downward market trends prevailed on the stock market in 2008. Despite the shrank size of the economy, 


\begin{tabular}{|c|c|c|c|c|c|c|c|c|c|c|c|c|c|c|c|c|}
\hline ํㅗㄹ & $\begin{array}{l}\text { Oे } \\
\text { o } \\
\text { s. }\end{array}$ & 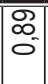 & $\overline{8}$ & ్ָ & $\mid \bar{\delta} \bar{\delta}$ & 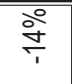 & 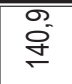 & \begin{tabular}{l|}
0 \\
0 \\
0
\end{tabular} & के & $\begin{array}{l}\circ \\
\\
\infty\end{array}$ & 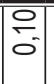 & के & $\begin{array}{l}\text { O } \\
\text { i } \\
\text { d }\end{array}$ & $\bar{\nabla}$ & ¿00 & $\frac{c}{0}$ \\
\hline ন্̀ & $\begin{array}{l}\text { m. } \\
\text { స్ }\end{array}$ & \begin{tabular}{|l|} 
\\
0 \\
0 \\
0
\end{tabular} & iั & 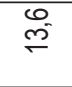 & $\bar{\delta}$ & ઠे. & $\bar{g}$ & \begin{tabular}{|l|}
8 \\
0
\end{tabular} & ฉิ઼ & 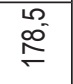 & 응 & ஓे & 웅 & $\cong$ & 8 & 0 \\
\hline$\stackrel{m}{\stackrel{2}{2}}$ & 促 & \begin{tabular}{|l|} 
\\
$\infty$ \\
$\infty$ \\
0 \\
0
\end{tabular} & ৯े & $\widehat{\Phi}^{-}$ & $\bar{\delta}$ & ০ั & ले & \begin{tabular}{|l|}
0 \\
0
\end{tabular} & ০ั & 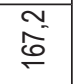 & 응 & $\stackrel{\circ}{\leftarrow}$ & $\begin{array}{l}\text { 웅 } \\
\text { o }\end{array}$ & $E_{0}$ & 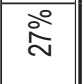 & $\frac{\pi}{\pi}$ \\
\hline 고ำ & 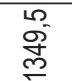 & 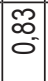 & ঃ̊ & $\begin{array}{l}\infty \\
\infty \\
\infty\end{array}$ & $\bar{\delta}$ & $\stackrel{\circ}{\circ}$ & $\begin{array}{l}\text { O্] } \\
\stackrel{9}{0}\end{array}$ & $\begin{array}{l}F \\
\bar{\sigma}\end{array}$ & ㅇํㅁ & సิ & 응 & $\stackrel{\circ}{2}$ & $\begin{array}{l}\text { 尺్ } \\
\text { ó }\end{array}$ & 要 & ฟิ & \\
\hline $\overrightarrow{\text { N }}$ & $\begin{array}{l}\text { న్ } \\
\text { న్ }\end{array}$ & \begin{tabular}{|l|} 
\\
$\mathscr{2}$ \\
$\infty$ \\
0
\end{tabular} & ஓे & 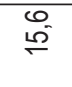 & $\bar{\delta}$ & ஓे & $\hat{\widetilde{\Xi}}$ & $\frac{1}{0}$ & @̊ & 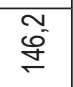 & \begin{tabular}{|l|}
8 \\
0
\end{tabular} & $\stackrel{\circ}{i}$ & $\begin{array}{l}8 \\
\stackrel{0}{1}\end{array}$ & 周 & 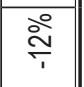 & \\
\hline 옴 & $\begin{array}{l}10 \\
\infty 0^{10} \\
\stackrel{10}{=}\end{array}$ & $\begin{array}{l} \\
0 \\
0 \\
0\end{array}$ & $\stackrel{\circ}{\checkmark}$ & $\begin{array}{l}\circ \\
\stackrel{\circ}{\forall}\end{array}$ & $\bar{\delta}$ & 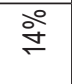 & $\stackrel{m}{\bar{N}}$ & \begin{tabular}{|l|}
0 \\
0 \\
\end{tabular} & $\stackrel{\circ}{\circ}$ & 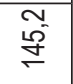 & 응 & $\stackrel{\circ}{\frac{1}{1}}$ & 음 & 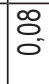 & ڤे & \\
\hline 오 & $\begin{array}{l}\hat{0} \\
\mathscr{D}^{\circ}\end{array}$ & \begin{tabular}{|l}
$\hat{N}$ \\
$0^{-}$
\end{tabular} & $\stackrel{\circ}{\stackrel{9}{~}}$ & $\stackrel{\varphi}{E}$ & $\bar{\delta}$ & ㅇํㅁ & $\begin{array}{l}\mathscr{O}^{-} \\
\stackrel{\infty}{\leftarrow}\end{array}$ & ma & $\stackrel{\circ}{\grave{N}}$ & $\begin{array}{l}\infty \\
\infty \\
\infty \\
\end{array}$ & 응- & @̊ & $\begin{array}{l}R \\
8 \\
85\end{array}$ & 응 & ळ0 & \\
\hline ণ্ট & 芦 & $\begin{array}{l}0 \\
\infty \\
0 \\
0\end{array}$ & ळे & 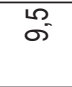 & $\bar{\delta}$ & ○े & $\begin{array}{l}m \\
m^{2} \\
m^{2}\end{array}$ & $\bar{\sigma}$ & ণे & $\begin{array}{l}\text { న্ } \\
\text { 心్ }\end{array}$ & $\bar{E}$ & $\stackrel{\circ}{\circ}$ & $\begin{array}{l}8 \\
0 \\
0\end{array}$ & 8 & ஓे & \\
\hline 홍 & m & $\tilde{O}_{0}$ & iั & M & $\bar{\delta}$ & 음 & $\begin{array}{l}\text { 음 } \\
\text { 욤 }\end{array}$ & $\underset{0}{\cong}$ & 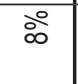 & $\stackrel{+}{\stackrel{\Xi}{c}}$ & $\bar{\sigma}$ & i̊ & $\begin{array}{l}\text { 足 } \\
\stackrel{\text { m}}{2}\end{array}$ & E. & ฟิ & \\
\hline ৫্ট & 芳 & 志 & $\stackrel{\circ}{\infty}$ & $0^{\circ}$ & $\bar{\delta}$ & $\stackrel{\circ}{\circ}$ & 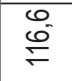 & $E_{0}$ & ڤั & $\begin{array}{l}0 \\
\infty \\
0 \\
0\end{array}$ & $\begin{array}{l}\text { 응 } \\
0\end{array}$ & ڤิ & $\frac{6}{8}$ & O & ஓ্ণ & \\
\hline ઠొి & $\begin{array}{l}6 \\
\infty \\
\infty \\
\infty\end{array}$ & \begin{tabular}{|l|}
\multicolumn{1}{|c|}{} \\
0 \\
0
\end{tabular} & ळे & $\begin{array}{l}\text { m } \\
\omega^{2}\end{array}$ & \begin{tabular}{|c|}
$\delta$ \\
\end{tabular} & ळั & $\overline{\varnothing 0}$ & Oי & \&্ণ & ৫্. & $\begin{array}{l} \\
\\
0\end{array}$ & ১̊ & $\frac{5}{6}$ & $\begin{array}{l} \\
\end{array}$ & ㅇํㅁ & \\
\hline 오 &  & \begin{tabular}{|l|}
$\infty$ \\
0 \\
0 \\
0 \\
\end{tabular} & 今̊ & $\underset{\forall}{\sim}$ & $\begin{array}{l}8 \\
0 \\
\end{array}$ & ㅇํㄴ & 竎 & 응 & ১্ & 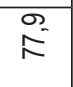 & \begin{tabular}{|l|}
$\infty$ \\
0 \\
0
\end{tabular} & ஓे & $\begin{array}{l}\text { 㔯 } \\
\text { m }\end{array}$ & O & ळे & \\
\hline ஜ્ڤે & $\begin{array}{l}\text { m. } \\
\stackrel{8}{+} \\
\infty\end{array}$ & \begin{tabular}{|l|}
$\infty$ \\
0 \\
0 \\
0
\end{tabular} & $\stackrel{\circ}{\circ}$ & $m^{m}$ & $\begin{array}{l}8 \\
0 \\
\end{array}$ & ১̊̊ి & $\begin{array}{l}\underbrace{\prime}_{f} \\
\text { fo }\end{array}$ & 녕 & 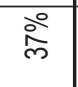 & $\widehat{\hat{\sigma}}$ & \begin{tabular}{|l|} 
\\
0 \\
0
\end{tabular} & ஓे & స్ & O & $\stackrel{\circ}{\stackrel{0}{m}}$ & \\
\hline ণั & 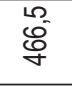 & \begin{tabular}{|l|}
$\infty$ \\
10 \\
0 \\
\end{tabular} & $\stackrel{\circ}{\text { †े }}$ & $\stackrel{20}{\sim}$ & $\begin{array}{l}8 \\
0\end{array}$ & ํํํ & $\sum_{\infty}^{\infty}$ & $\begin{array}{l} \\
0 \\
0\end{array}$ & i̊ & $\stackrel{0}{\omega}$ & 周 & ํํํ & $\begin{array}{l}\text { O్ } \\
\ddot{N}\end{array}$ & Oי. & ळें & \\
\hline 홍 & $\widehat{\overline{8}}$ & \begin{tabular}{|l|}
0 \\
0 \\
0
\end{tabular} & i̊ & $\stackrel{\infty}{\leftarrow}$ & $\begin{array}{l}8 \\
0\end{array}$ & ১̊̊ & $\begin{array}{l}10 \\
0 \\
\end{array}$ & $\begin{array}{l}0 \\
0 \\
0\end{array}$ & ه্ণে & $\begin{array}{l}\text { No } \\
\text { o }\end{array}$ & $\begin{array}{l}8 \\
0 \\
\end{array}$ & సิ & $\stackrel{m}{\stackrel{m}{\leftrightarrows}}$ & $\tilde{O}$ & ষ̊ & \\
\hline 음 & 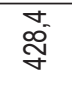 & \begin{tabular}{|l|}
5 \\
0 \\
0
\end{tabular} & ठீ & $\cong$ & $\begin{array}{l}8 \\
0\end{array}$ & ஸे & 官 & ঙே் & ه্ণ & $\begin{array}{l}\text { S } \\
\text { m. }\end{array}$ & \begin{tabular}{|l|}
\multirow{0}{*}{} \\
0 \\
\end{tabular} & $\stackrel{\circ}{\circ}$ & ָ̊ & $\bar{\delta}$ & ঃి & \\
\hline ஓ & $\overrightarrow{\text { ల్ల }}$ & \begin{tabular}{|l|}
\multirow{2}{*}{} \\
0 \\
0
\end{tabular} & ڤे & Os & $\begin{array}{l} \\
\\
\end{array}$ & ণ̊ & ه্ণে & ঙேं & ه্ণে & 요 & $\begin{array}{l} \\
0 \\
0\end{array}$ & \&̊ & $\frac{\sigma}{m}$ & 8 & ठें & \\
\hline$\stackrel{\infty}{\stackrel{2}{2}}$ & $\widehat{\bar{\infty}}$ & \begin{tabular}{|l|} 
\\
$\tilde{2}$ \\
0 \\
\end{tabular} & $\stackrel{\circ}{\rightleftharpoons}$ & $\mathscr{O}_{0}^{\circ}$ & $\begin{array}{l}8 \\
0 \\
\end{array}$ & i̊ & ه্ণ & 宊 & ه্் & $\overline{\mathbf{N}}$ & $\begin{array}{l}3 \\
0 \\
0\end{array}$ & ㅇํํ & $\stackrel{\infty}{-}$ & 8 & $\stackrel{\circ}{\circ}$ & \\
\hline g্ & 离 & 等 & ه্ণে & tr & $\begin{array}{l} \\
\end{array}$ & $\stackrel{\text { வேं }}{\check{\Sigma}}$ & ه্ণে & 囟 & ه্ণে & $\tilde{m}$ & $\begin{array}{l}2 \\
0 \\
0\end{array}$ & ه্்ে & 욛 & 8 & 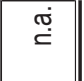 & \\
\hline & 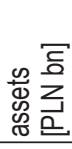 & 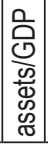 & 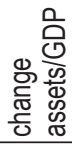 &  & 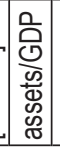 &  & 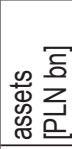 & 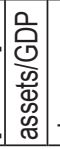 & 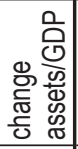 & 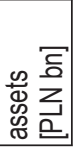 & 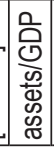 & 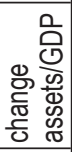 & 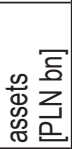 & 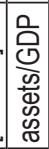 & 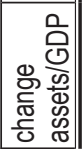 & . \\
\hline & 10100 & & ueq & & $\begin{array}{r}\text { (t) } \\
\text { oḷun }\end{array}$ & 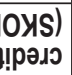 & spun & if uc & !suad & & & & & dnf I & ţnu & \\
\hline
\end{tabular}


the ratio described above declined about $48 \%$ to the 0.06 level. The recovery in importance of that group of financial intermediaries for the economy and the persistent rebuilding of trust on part of individual investors have led to the present situation, where the mutual funds market, although to a much smaller extent than the banking sector, still continues to provide additional opportunities for investment other than in assets directly allocated in the capital market or savings deposits on bank accounts. The share of funds' assets in GDP in 2015 amounted to 0.14, which evidences the growing importance of this group of financial intermediaries.

The relatively early initiated process of transformations has enabled the unrestricted functioning of financial intermediaries other than banks since the onset of the 1990s decade. After a period of profound political and economic transformations, the market-driven financial system was developed, followed by a period when a number of insurance companies was growing in Poland. The development of such institutions was accompanied by a declining disproportion between the number of life insurance and non-life insurance companies owing to a relatively high competition on the market and the maintaining of some products bellow the profitability level. Table 1 presents, among others, the growth rate of insurance market in Poland. The value of assets held by insurance companies went up from PLN 13.2bn in 1997 to PLN 180bn in 2015, which means an annual average growth of $19 \%$. The share of insurance companies' assets in the GDP oscillated around 0.10 for a long time, which can be regarded as confirmation that the rate of insurance service market's growth was in proportion to the development of the entire Polish economy. As already mentioned above, the high rate of internal competition as well as the interception of some insurance products by the banking sector, which was made possible due to the technological progress and clients' needs for financial service - they all seem to be the market changes strongly affecting the perspective of insurance companies development.

In turn, the pension system reform, reconstructed at the second half of 1990s, resulted in the appearance of a relatively large number of asset management companies so that part of wherewithal could be provided for pensions upon workers' retirement. During the first year of their functioning, the assets of pension funds totaled PLN $19.5 \mathrm{bn}$, which represented 0.03 share in the GDP (see Table 1). Next years witnessed an increase of the market value, e.g. the assets of the sector were valued at PLN 299.3bn in 2013 with the 0.18 ratio of assets to the GDP. Once some changes in the open pension funds (OFE) were enacted in 2014, an obligatory reallocation of a part of savings from the pension funds' clients to the Social Insurance Institution 
(ZUS) followed, which resulted in the reduction of assets under management accompanied by the falling importance of pension funds in the economy. In 2015, the value of pension fund assets totaled PLN 140.9bn with a 0.08 share in the GDP. Some other changes announced in the functioning of OFE can drastically transform the picture of the entire market.

The functioning of credit unions (SKOK) supplements the banking sector operations in a certain way. Since 2011, the entities began to be included in the obligatory system of deposits guarantee under the Bank Guarantee Fund, which meant increased security of assets deposited by clients. However, the current situation caused by some financial problems and faced by some institutions in this group negatively influenced not only the perception of the sector as a whole but its further development as well. The share of SKOSs' assets in the GDP during the whole period under study did not exceed 0.01.

The view on different types of financial intermediaries as competitors of mutual funds allows to the presentation of conditions of the mutual funds functioning while competing for clients' savings. Figure 1 shows the market shares of the main types of financial intermediaries.

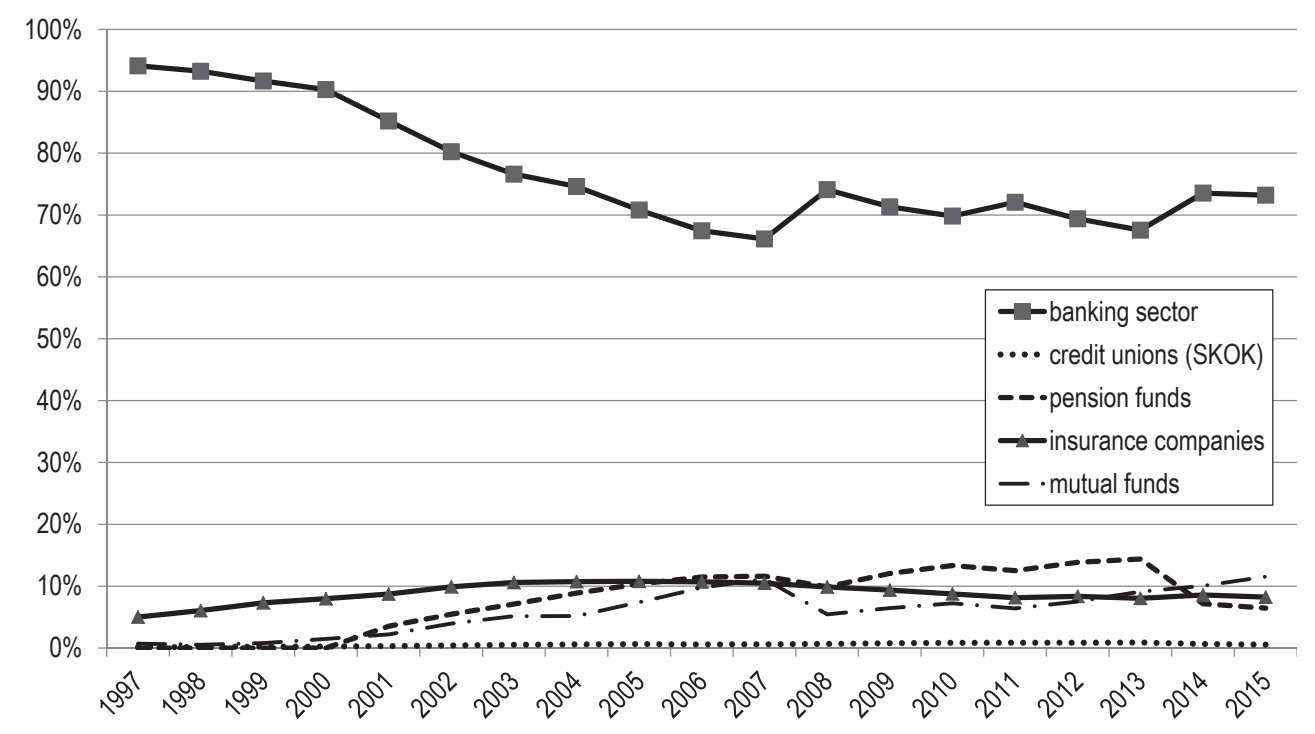

Figure 1. The market shares of main types of financial intermediaries

Source: author's elaboration on the basis of annual reports of the National Bank of Poland (NBP) and the Polish Financial Supervision Authority (KNF). 
The year 1997 marks the starting point of the analyzed period as this is when the development of mutual funds gained momentum. The increasing demand for financial intermediaries resulted not only in the increased value of assets held by individual entities, but also in some changes in the existing structure of financial market as well. The changes in offers of individual institutions were caused to a large degree by securities market situation, which was favorable for investments. In spite of the above-mentioned, increasingly important and impregnable position of the banking sector in Polish economy, there was space for the possible development of nonbanking intermediaries almost right from the onset of the whole period under study. As shown in Figure 1, the share of banking assets in the total assets of financial intermediaries was practically around $90 \%$ until 2000 . In the following years the market share of the banking sector was gradually decreasing until 2007. As the aftermath of the financial crisis symptoms present also in the Polish market, that tendency was brought to a halt. At the end of 2015, the share of banking assets in the total assets on the intermediaries' market was $73 \%$. During almost the whole period under study, the non-threatening but noticeable competitors for the above groups were found amongst insurance companies having the market share of $8-11 \%$.

The detailed analysis of financial intermediaries' market in Poland leads also to some conclusions about other groups of entities. Pension funds and mutual funds were successful in their operations starting from 2000. In 2007 , the ratio of the banking sector assets to the total asset on the market fell down to $66 \%$, but that of the collective investment institutions increased to $12 \%$ and $11 \%$, respectively. In the crucial year 2008 , position of banks on the market improved compared to that of other financial intermediaries in Poland, mainly due to the downturn on the market. Moreover, the total market share of the other intermediaries never went above the level reached that year. In general, the development of collective investment institutions in Poland is an unquestionable fact confirmed by all statistics concerning, e.g. the value of assets held by mutual funds. The primary role of banks in the economy continues to be a factor restricting their growth and, as was observed in the case of pension funds, also due to some reforms concerning their functional environment. 


\section{Some selected aspects regarding the development of mutual fund industry in Poland}

\subsection{Measurement of the market size and the industry development from the product viewpoint}

The process of reconstructing financial markets in Central-Eastern European countries, including Poland, began in 1989. Their development in subsequent years allowed the launching of activities related to collective investments of market institutions. The entry into force of the Act of 22 March 1991 on the Public Trading in Securities and Trust Funds enabled the inauguration of investment fund companies. The first trust fund, "Pioneer Pierwszy Polski Fundusz Powierniczy", started operating in July 1992. At the very beginning, investment funds were playing only a marginal role from the viewpoint of both, investors on the capital market and the whole economy (Al-Kaber, 2000). However, along with the heightened awareness on capital markets amongst the public and their increased propensity to saving, the mutual fund market in Poland was becoming a place where the clients' expectations were satisfied with regard to alternative forms of investment.

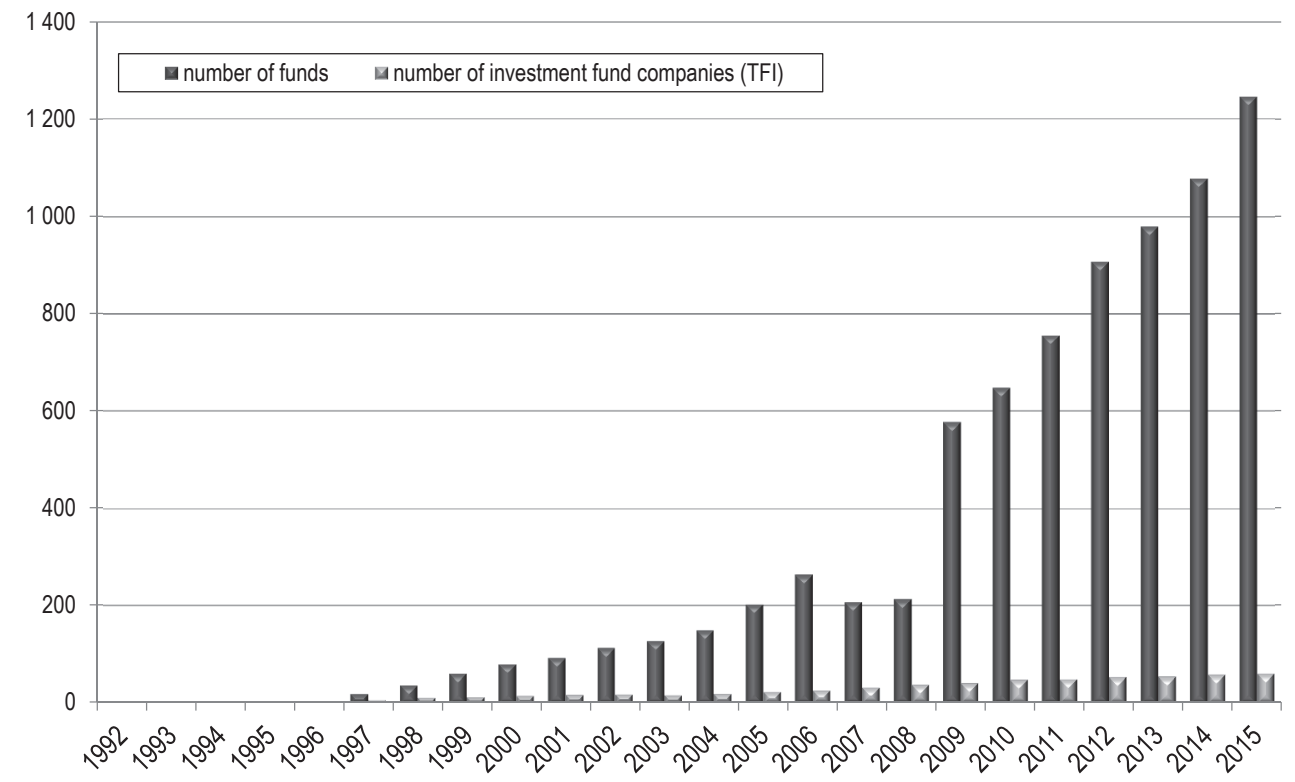

Figure 2. The number of mutual funds operating in Poland in the 1992-2015 period

Source: author's elaboration on the basis of Pochmara and Zapała (2004) and annual reports of the Chamber of Fund and Asset Management (IZFiA). 
One of the indicators of the market development is a number of entities operating on a given market. Figure 2 presents a number of mutual funds as well as a number of investment fund companies (TFIs) operating in Poland in the 1992-2015 period, including all types of funds.

The pace of development can be illustrated by the fact that, while there were only 3 investment fund companies managing 5 funds at the end of 1996, their number went up to 7 investment fund companies managing as many as 20 funds at the end of 1997 . The decisive moment for that sector was observed back in 1998, when the Act of 28 August 1997 on Mutual Funds came into force. Instead of the existing trust funds, the notion of openended mutual funds was introduced and, modelled after the American system, each fund was given a legal personality. As presented in Figure 2, from that moment the permanent dynamic growth of mutual funds' number in Poland could be observed. At the end of 2004 , the number of funds totaled 150, while in the years 2005 or 2006 their number increased to 203 and 263, respectively. A clause in the amended Act on Mutual Funds of 2007 provided about the possibility of establishing some new types of funds, for example fund of funds, which resulted in a number of funds increased even further. However, the next two years brought about the decrease of their number, which followed from substantial changes on the financial markets due to the global economic crisis. The investment fund companies started to offer a wider range of products, which happened simultaneously with the long-awaited upturn on the securities markets. In 2009, the register of mutual funds listed as many as 578 funds managed by 42 TFls. The next period followed, which was the time of sustainable development of the whole industry. Further market growth was also largely attributable to the amended Act on Mutual Funds and the Act on Financial Market Supervision as they allowed the implementation of the European Union regulations concerning financial market into Polish legal system (especially the Directive 2009/65/ EC of the European Parliament and of the Council of 13 July 2009 on the coordination of laws, regulations and administrative provisions relating to undertakings for collective investment in transferable securities, the so-called UCITS-IV). At the end of 2015, as many as 1246 mutual funds managed by 46 TFIs were operational in the Polish market (IZFA, 2016).

The volume of the fund units purchases may be a way to measure the offer available on the market. Figure 3 presents increased interest in mutual funds in Poland as reflected by the volume of assets entrusted to the funds. On the left scale, the net values of assets are collated, while the one on the right presents the dynamics of changes in percentage terms. 


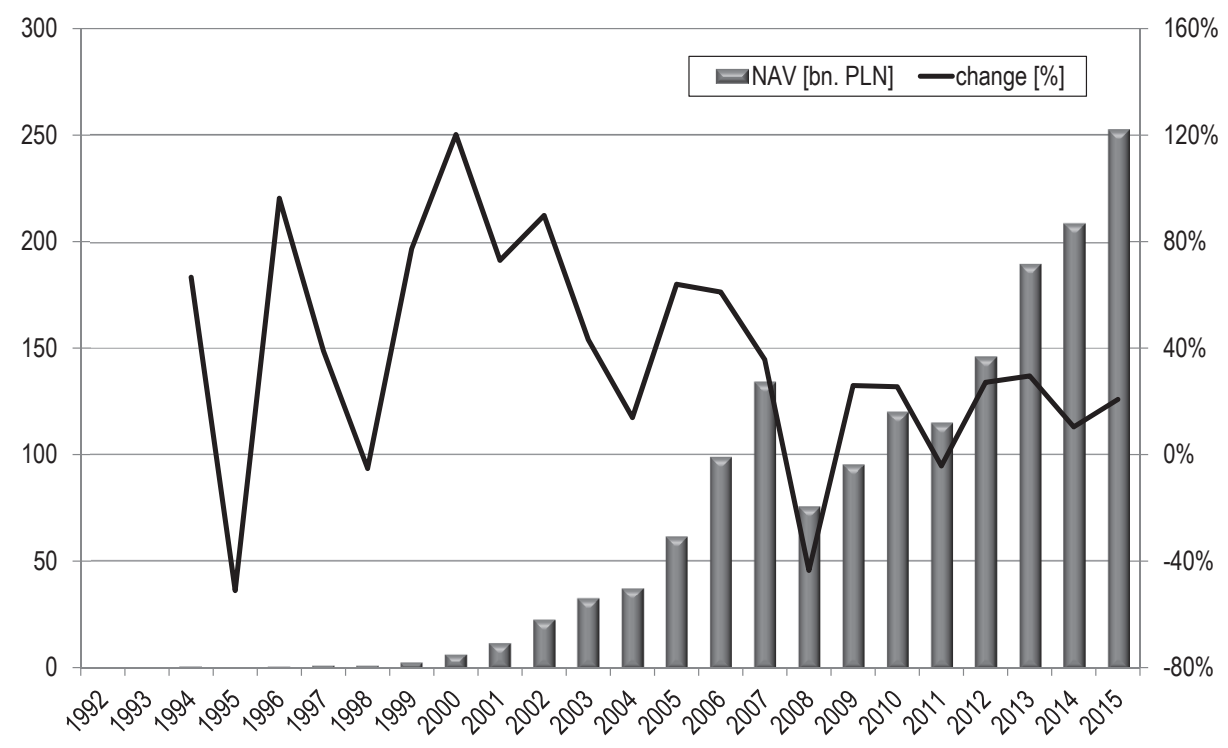

Figure 3. The net asset value of mutual funds and their change dynamics

Source: author's elaboration on the basis of Pochmara and Zapała (2004) and annual reports of the Chamber of Fund and Asset Management (IZFiA).

Besides the number of entities operating on the market, a net asset value may also be perceived as a measure to determine the rate of industry development. The annual value of the mutual fund market in Poland in the first 7 years of their functioning did not exceed PLN 2bn. A discernible growth in the value of assets managed by the analyzed entities resulted, to a certain extent, from the growing popularity of these types of financial intermediaries among individual investors, as observed already in 1999 and 2000, when the value of the fund's allocated units totaled around PLN 3.2bn, and over PLN 7bn, respectively. At the same time, it was a period of the biggest annual growth in the assets value, when the $120 \%$ increase was noted (see: Fig. 3). However, the real boom on the market took place in subsequent periods. In 2001, the total value of located assets exceeded PLN 12.1bn, while in 2007 it increased over tenfold to reach PLN 134.5bn. The boom on the securities market observed at that time was accompanied by the funds enjoying an increased inflow of assets. Nevertheless, the economic downturn in 2008 caused by the global financial crisis was observed in Poland and impacted the level of assets under fund management. The wave of withdrawals and falls of stock prices on the capital markets brought about the decrease of asset value by almost a half (the fall of $43 \%$ over to the previous year), and it went down to 
PLN 76bn. For the next two years, the mutual funds tried to rebuild the trust of their clients in an arduous way after the period of suffering their largest losses. The annual dynamics of assets' changes at that time amounted to approx. 25\%. Once again in 2011, the mutual funds market faced some negative developments, partly due to the euro-zone crisis. In the case of Polish mutual fund industry, this adverse trend prevailed for a short time only. Since 2012 , an increase in the value of assets was achieved and the upturn market conditions could be observed once again. At the end of 2015, the value of the market totaled PLN 252.4bn, which means an increase of about $88 \%$ over to the year preceding the 2007 crisis. To conclude, it needs to be said that, in accordance with the analysis presented here, the development of the mutual fund industry cannot be challenged. However, it can also be noticed that there is some dependence between the clients' interest in financial intermediaries and the economic situation prevailing on the securities markets at a given moment. The comparative analysis of the two mentioned variables needs further consideration by taking a separate approach.

\subsection{The structure of mutual fund industry}

One of the main aims of the study was to present the trends in savings entrusted to financial intermediaries by final market participants, including in particular the institutions of collective investment. The analysis of structure of the market has enabled the identification of trends concerning the popularity of individual fund segments. Market shares of major segments are collated in Figure 4.

Volumes of main segments of funds' shares in the total assets of the sector are presented in Figure 4. The classification of funds adopted in this paper needs to be explained at this point. According to an economic criterion applied by Chamber of Fund and Asset Management (IZFiA, 2016), all mutual funds can be grouped, in a simplified way, into the fix-income, mixed and aggressive investment categories. The first one comprises bond funds as well as money market funds, whereas the second group of mixed funds includes balanced funds, growth and income funds and other mixed funds (e.g. active allocation or absolute return funds). The category of aggressive funds includes mainly stock (equity) funds, but, since 2008, most fund companies have introduced a subcategory of aggressive funds, which was non-public assets funds. The other funds are those that cannot be classified in any of the categories mentioned above. They are the property (real estate) funds, those focused on natural resources (raw material) or the exchange traded funds (ETFs). 


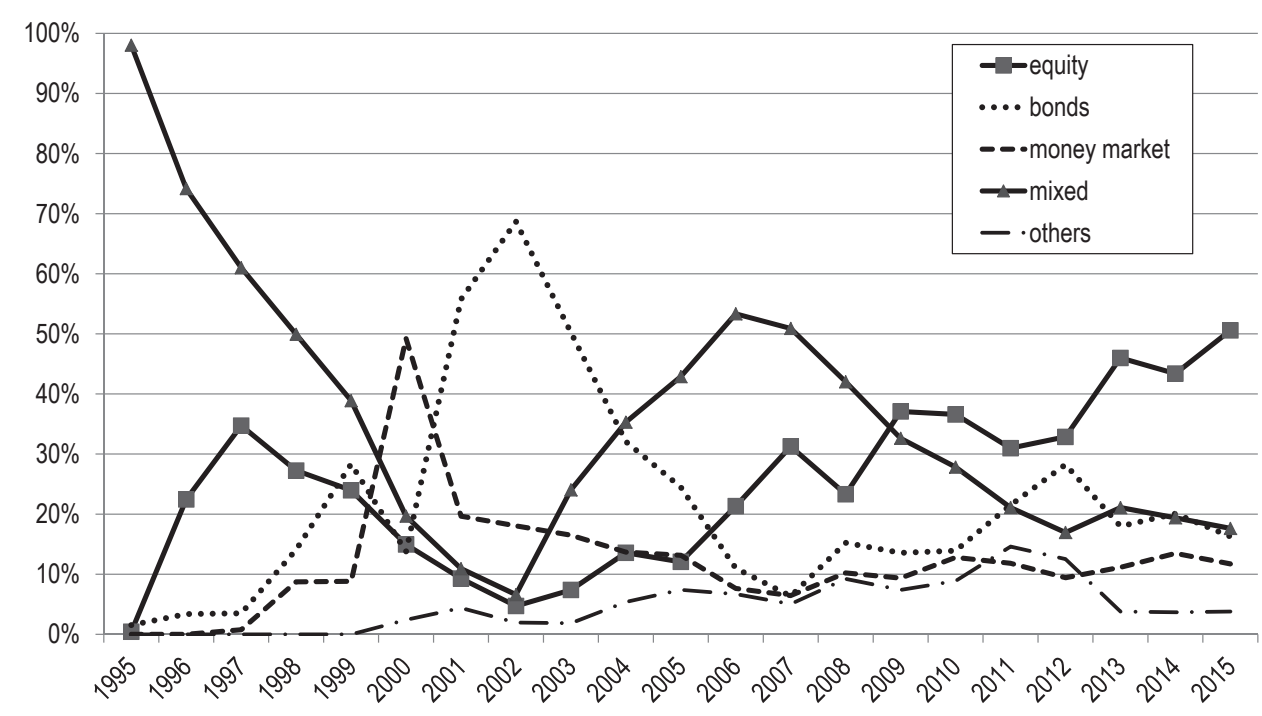

Figure 4. The market share of main segments of funds

Source: author's elaboration on the basis of annual reports of the Chamber of Fund and Asset Management (IZFiA).

As presented above, the analysis shows that domination of any segment of funds has not been decided yet. The volume of market shares of the main types of funds has changed over time in some periods, which could depend on market factors. An increase of the level of assets located in aggressive funds has corresponded to a specific decrease in the shares of investments in debt securities funds. It is particularly noticeable in the prosperity periods. Along with downs in the stock markets, in turn, and as a result of investors' leaving aggressive holdings, the growth of fix-income funds' share could be observed. Recorded in 2015, the increase of market share of equity funds to $51 \%$ was caused by classifying non-public assets funds since 2008 in the group of aggressive funds, which were very popular in the last few years. Nevertheless, the conclusions drawn basing on the above collation should be expanded further in some additional studies, where subgroups of funds in the main segments need to be analyzed.

\section{Concluding remarks}

This study has partly discussed some of the conditions and possibilities in the functional environment of mutual funds operating in Poland, which are presented against the background of some selected participants of the 
financial system. The aim of the study was to present the structure of the financial intermediaries market, with particular reference to mutual funds, and to define the role they play in the financial sector. Furthermore, from cognitive perspective, determining the influence of market trends on the popularity of given segments of the fund market has also been an important consideration.

The analysis has showed that the development of collective investment institutions in Poland is incontestable. It has been confirmed by all statistics, including those on the level of assets under management. Some threats for mutual funds may be posed by the fact that banks in Poland as well as in other markets in the CEE countries have a very strong position on the market, which, among other things, is confirmed by the banks' domination in the structure of savings deposited with financial intermediaries by the final market participants. Therefore, mutual funds play a secondary role on the financial intermediaries market. On the other hand, the noticeable and positive situation on the stock market, observed mostly throughout the period under study, has been conducive to the dynamic development of collective investment institutions. It is the periods of upward market trends and the subsequent changes in relevant legislation that have resulted in good conditions fostering development of the market. The growth of main indices on the stock exchange, creating opportunities to achieve good investment results, triggered the growing popularity of mutual funds. Fluctuations of the level of interest in the intermediaries were generally limited only to the choice of the funds segments.

\section{References:}

Al-Kaber, M. (2006). Rynki finansowe i instytucje [Financial markets and institutions]. Wydawnictwo Wyższej Szkoły Ekonomicznej w Białymstoku, Białystok.

Blake, D. (2000). Financial Market Analysis, John Wiley \& Sons, 2nd edition, London.

Czekaj J., Woś M. \& Żarnowski J. (2001). Efektywność giełdowego rynku akcji w Polsce. Z perspektywy dziesięciolecia [Effectiveness of stock market in Poland], Wydawnictwo Naukowe PWN, Warszawa.

Czempas J. \& Lokwenc P. (2001). Opłacalność inwestycji w fundusze inwestycyjne w 2000 roku [Profitability of investments in mutual funds]. „Nasz Rynek Kapitałowy", No. 6-7,72-78. 
Ferreira, A.M., Keswani, A., Miguel, A.F. \& Ramos, S.B. (2013). The Determinants of Mutual Fund Performance: A Cross-Country Study. „Review of Finance", No. 17(2), 483-525.

Filip, D. (2007). Fundusze inwestycyjne w Polsce, Czechach i na Węgrzech [Mutual funds in Poland, the Czech Republic and Hungary]. "Master of Business Administration", No. 4 (87), 18-27.

Filip, D. (2015). A survey on important issues related to the organizational factors affecting mutual fund performance. In: Proceedings of IAC-MEM 2015 in Vienna, (pp. 84-89), Czech Institute of Academic Education, Prague.

Friend, I., Brown, F.E., Herman, E.S. \& Vickers, D. (1962). A Study of Mutual Funds. U.S. Government Printing Office, Washington, D.C.

Horowitz, I. (1965). A Model for Mutual Fund Evaluation. „Industrial Management Review, No. 6, 81-92.

Investment Company Institute, ICI (2016) A Guide to Understanding Mutual Funds, available at www.ici.org access 09.10.2016.

IZFiA (2016) Raport roczny za 2015 rok Izby Zarządzających Funduszami i Aktywami [Chamber of Fund and Asset Management Annual Report 2015], April 2016, available at http://www.izfa.pl/ access 26.11.2016.

Jackowicz, K. \& Filip, D. (2009). Powtarzalność wyników funduszy inwestycyjnych $w$ Polsce [Performance persistence of mutual funds in Poland]. Materiały i Studia nr 236, NBP, Warszawa.

JP.Morgan (2016). A Guide to Mutual Fund Investing, available at www.chase. com, access 12.09.2016.

Khorana, A. \& Servaes, H. (2008). On the Future of the Mutual Fund Industry around the World. In: Fuchita, Y. and Litan (eds.), Pooling money: the future of mutual funds, Brooking Institution.

Khorana, A., Servaes, H. \& Tufano, P. (2005). Explaining the size of the mutual fund industry around the world, „Journal of Financial Economics”, No. 78, 145-185.

Matysek-Jędrych, A. (2007). Struktura i modele systemu finansowego [The structure and models of the financial system]. „Bank i Kredyt”, No. 11-12, 87-102.

Miziołek, T. (1997). Ocena efektywności inwestowania w fundusze powiernicze [The evaluation of efectiveness of investment funds]. „Nasz Rynek Kapitałowy", No. 11, 37. 
Olbryś, J. (2010). Ocena efektywności zarządzania portfelem funduszu inwestycyjnego z wykorzystaniem wybranych wieloczynnikowych modeli market-timing [Selected Multifactor Market-timing Models for Mutual Fund Performance Evaluation]. „Optimum” Studia Ekonomiczne, No. 4(48), 44-61.

Perez, K. (2012). Efektywność funduszy inwestycyjnych. Podejście techniczne i fundamentalne [The effectiveness of mutual funds. Technical and fundamental approach]. Difin, Warszawa.

Pochmara, W. \& Zapała, A. (2004). Prawa uczestnika funduszu inwestycyjnego i sposób ich realizacji [Rights of mutual fund' participant and the ways of their realization]. KPWiG, Warszawa.

SEC (2008). Mutual Funds: A Guide for Investors. SEC Pub. 002 (08/07).

Sharpe, W.F. (1966). Mutual Funds Performance. "Journal of Business”, No. 39(1), 119-138.

Sikora T. (2010), Analiza wyników funduszy inwestycyjnych w Polsce z wykorzystaniem wnioskowania bayesowskiego [The Analysis of Investment Funds Performance in Poland with Applied Bayesian inference]. Materiały i studia nr 248, NBP, Warszawa.

Treynor, J.L. (1965). How to Rate Management of Investment Funds. Harvard Business Revi. 